\title{
Teachers' Knowledge and Perception about Dyslexia: Developing and Validating a Scale
}

\author{
Duygu Tosun (iD) 1,, Serkan Arikan (iD), Nalan Babur (iD)1
}

${ }^{1}$ Bogazici University, Faculty of Education, Istanbul, Turkey

\begin{abstract}
ARTICLE HISTORY
Received: Feb. 04, 2020

Revised: Feb. 28, 2021

Accepted: Mar. 16, 2021

Keywords:

Scale development, Measurement invariance, Teacher knowledge of dyslexia, Teacher perception of dyslexia,

Abstract: Teachers have an important role in the achievement progress of students with dyslexia. Therefore, measuring teachers' knowledge and perception of dyslexia is important. Given that an instrument that measures both teachers' knowledge and perception of dyslexia is not available, this study aims to develop a scale to measure primary school teachers' knowledge and perception of dyslexia. Two hundred and one primary school teachers participated in the study, and exploratory factor analysis was conducted to identify the dimensions of the scale and to select scale items. Configural, metric and scalar invariance across gender groups was supported. This study also examines whether teachers' knowledge and perception of dyslexia differ with regard to their backgrounds. The results showed that there was no significant relationship between primary school teachers' teaching experience and their knowledge of dyslexia. Also, their knowledge of dyslexia did not differ with regard to other variables of the study. On the other hand, there was a positive, but weak relationship between teaching experience and teachers' negative perceptions of dyslexia. Primary school teachers who took a course about dyslexia in college had lower negative perceptions of dyslexia than teachers who did not do so. Teachers' perceptions did not differ with regard to taking an in-service seminar, reading a book or an article or teaching a student with dyslexia. The current study is expected to contribute to dyslexia research in terms of providing a scale to measure teachers' knowledge and perception of dyslexia.
\end{abstract}

\section{INTRODUCTION}

Learning to read is the primary goal for the first years of schooling. Students acquire reading skills through a systematic literacy education which mostly depends on language-based activities offered by teachers. Teachers are critical figures and play a significant role in teaching reading acquisition. General education or special education teachers who are specifically trained for effective reading instruction might be among the first to detect learning difficulties in students. Furthermore, teachers have a much more important role for students with dyslexia. Dyslexia is a language-based learning difficulty that affects word reading, spelling, and writing (Proctor et al., 2017; Vellutino et al., 2004).

It is reported that $80 \%$ of students who need special education suffer from dyslexia (National Center for Statistics, 2008). Demir (2005) reported that, according to parent surveys, $33 \%$ of the students in first grade were at risk for dyslexia in Turkey. On the other hand, first grade 
teachers indicated that $25 \%$ of first grade students displayed increased difficulties while learning to read and write (Demir, 2005). Research has shown that with the help of a teacher who provides appropriate reading instruction, students with dyslexia may have better academic success (e.g., Bos et al., 2001; Hornstra et al., 2010; Moats, 2009; Moats \& Foorman, 2003; Rubin, 2002; Snow et al., 1998). It is also reported that the reading achievement of dyslexic students, in particular, is affected by their teachers' knowledge and capabilities (e.g., GwernanJones \& Burden, 2010; Hellendoorn \& Ruijssenaars, 2000; Lane et al., 2009; Mills, 2006; Rubin, 2002). These studies proved that literacy acquisition should be done through effective and specialized approaches by a well-trained teacher (Brady \& Moats, 1997; Rubin, 2002). In order to assist students to improve their reading skills and access content curriculum, all teachers should be aware of the effective instructional strategies on literacy (Boling \& Evans, 2008; Gwernan-Jones \& Burden, 2010). Teachers should have a high level of reading instruction knowledge for effectively teaching students because their choice of instructional and intervention programing is affected and guided by their knowledge (Foorman \& Moats, 2004; Snow et al., 1998; Spear-Swerling \& Brucker, 2004). In other words, more knowledgeable teachers are better equipped to facilitate reading achievement in students relative to those with less knowledge (Snow et al., 1998; Spear-Swerling \& Brucker, 2004). Overall, more knowledgeable teachers are more likely to identify students with dyslexia compared to less knowledgeable ones (Gwernan-Jones \& Burden, 2010; Spear-Swerling, 2009; Taylor et al., 2002).

Besides teachers' knowledge of dyslexia, how they perceive dyslexia has an important effect on students with dyslexia. It is known that in addition to knowledge, teachers' perception of dyslexia also affects the capability of dealing with dyslexia. A teacher who has a negative perception of dyslexia would be expected to rate the achievement level of dyslexic students as low (Hornstra et al., 2010). This negative perception causes teachers to decrease their expectations from dyslexic students. On the contrary, teachers who have a correct understanding of dyslexia are more likely to help students overcome challenges posed by their disability (Hornstra et al., 2010).

Teachers play a significant role in identifying and including students with dyslexia, so having accurate knowledge of dyslexia is critical. Therefore, it is important to explore what teachers really know about dyslexia as well as their perceptions of it. In order to do so, it is necessary to evaluate them with a valid and reliable scale.

\subsection{Measuring Teachers' Knowledge and Perception of Dyslexia}

Teachers' knowledge and perception of dyslexia have attracted researchers' attention, and several studies have been conducted to measure teachers' knowledge and perception of dyslexia. For example, Ferrer, Bengoa, and Joshi (2016) investigated in-service and pre-service teachers' knowledge and beliefs of developmental dyslexia. They developed the Knowledge and Beliefs about Developmental Dyslexia Scale with 36 items. Every item in the scale is a statement about dyslexia and teachers are asked to evaluate the statements as true, false, or no idea. The scale measures teachers' knowledge and misconceptions about developmental dyslexia in three areas: General information about the nature, causes and outcome of developmental dyslexia, symptoms of developmental dyslexia and the treatment of developmental dyslexia. Their study indicated that teachers' knowledge was not correlated with their age and gender. A statistically significant correlation was found between pre-service teachers' scale scores and training about dyslexia in their university studies. In-service teachers' scale scores were significantly correlated with their years of teaching experience, postgraduate training about dyslexia, and prior exposure to a child with dyslexia. In-service teachers' knowledge of dyslexia was positively correlated to their self-confidence in teaching children with dyslexia. Washburn, Mulcahy, Musante and Joshi (2017) used a survey that included items 
about fluency, word study, vocabulary and comprehension. Besides demographic information, teachers were also asked to answer two open-ended questions measuring characteristics of reading disability and characteristics of dyslexia. The results showed that certification area, certification grade level and exposure to literacy-related content did not predict teachers' knowledge of reading disabilities.

Research shows that a teacher's beliefs and perceptions may affect their classroom behavior and shape their teaching style (Nijakowska et al., 2018). Some teachers may not openly express their perceptions about students with dyslexia. Such teachers may be emotionally loaded, which may impact their instructional practices negatively and lead to resistance to change. Nijakowska and colleagues (2018) report that there seems to be a two-way interaction between teacher perceptions and educational practices. Even though teachers need to have a positive perception and sufficient knowledge regarding students with dyslexia, literature shows that many general education and special education teachers are not adequately prepared to teach children with dyslexia (e.g., Aktan, 2020; Balcı, 2019; Bos et al., 1999; Esen \& Çiftçi, 2000; Furat \& Koçak, 2018; Mather et al., 2001; Moats, 2009; Şahin et al., 2020; Washburn et al., 2011). Teachers often may not be aware of their negative perception that may affect their teaching and attitudes towards children with dyslexia. When designing a professional training program, it is crucial to understand teachers' level of knowledge about dyslexia and their perception of students with dyslexia. Knowing teachers' perception of dyslexia may help researchers develop and design adequate professional training and teaching models.

In Turkey, although there are studies regarding dyslexia, these studies mainly focus on measuring the teachers' knowledge about dyslexia (Akçay, 2014; Altun et al., 2011; Altuntaş, 2010; Doğan, 2013; Yurdakal, 2014). Altuntaş (2010) and Doğan (2013) developed questionnaires and knowledge tests about dyslexia and used them as data-gathering instruments in their studies. Altun et al. (2011) conducted a qualitative study that used semi-structured interview techniques in the data collection process. However, these studies only measured teachers' knowledge of dyslexia. Research studies investigating teachers' knowledge and perceptions toward children with dyslexia are rare in Turkey (e.g., Başar \& Göncü, 2018; Gever, 2017; Şahin et al., 2020). We, therefore, decided to develop a scale that would help us obtain information about teachers' knowledge and perception related to dyslexia.

In sum, many studies have shown that primary school teachers are not well equipped for supporting and educating students with dyslexia. Results of these studies consistently displayed that many primary school teachers lacked the accurate knowledge about dyslexia and researchbased skills for teaching students with dyslexia (e.g., Aktan, 2020; Balc1, 2019; Esen \& Çiftçi, 2000; Firat \& Koçak, 2018; Şahin et al., 2020; Washburn et al., 2011).

\subsection{Correlates of Teachers' Knowledge and Perception of Dyslexia}

Studies emphasized that accurate knowledge and positive perception of dyslexia can help teachers to assist, teach and support students with dyslexia (Hornstra et al., 2010). For this reason, researchers investigated both teachers' knowledge and perception of dyslexia as well as the factors related to knowledge and perception. Ferrer et al. (2016) reported that in-service teachers' knowledge of dyslexia was related to the factors such as post-training of dyslexia, years of teaching experience, prior exposure to a dyslexic student, and high self-esteem. Washburn and colleagues (2017) conducted an exploratory study with 271 pre-service and inservice teachers in order to investigate novice teachers' knowledge about the characteristics of learning disabilities and dyslexia. Their findings showed that teachers had a clear understanding of learning disabilities when asked about reading disabilities, whereas they had misconceptions of dyslexia when asked about dyslexia. Their knowledge about learning disabilities and dyslexia was not dependent on certification type, certification grade level, or exposure to reading content. The results indicated that teachers listed more language and literacy-related 
characteristics with the term learning disability than with the term dyslexia, which showed that teachers were confused about the true definition of dyslexia.

When we examined dyslexia studies conducted in Turkey, for example, Altuntaş (2010) study showed that teachers' knowledge of dyslexia was not related to having a dyslexic student and the type of school they work. Teachers generally had insufficient knowledge about dyslexia and did not feel well-prepared to teach dyslexic students. Altun et al. (2011) found that every teacher faced reading disabilities in their classrooms. Teachers perceived themselves as insufficient in the area of reading disabilities and did not feel capable of teaching students who struggled with them. Doğan (2013) showed that the reading disability knowledge level of Turkish language teachers who teach secondary school level was higher than that of primary school teachers. Turkish language teachers were also more successful in identifying students with reading disabilities relative to primary school teachers. Another important finding of the study was that novice teachers were much more knowledgeable about reading disabilities than experienced teachers. Akçay (2014) designed a study to determine elementary school teachers' awareness of dyslexic students from grade one to grade four. The findings revealed that elementary school teachers' awareness level of dyslexia didn't change according to the gender, teaching experience, type of certification, type of faculty, the grade of students they teach, their beliefs about their qualifications, taking an in-service training, and the classroom size. On the other hand, Yurdakal (2014) reported that primary school teachers' knowledge level of dyslexia was adequate. Last but not least, one of the most recent studies conducted by Şahin et al. (2020) examined primary school teachers' knowledge and attitudes toward dyslexia. The researchers reported that even though most teachers had positive attitudes toward students with dyslexia, the lack of knowledge and not having effective teaching skills showed the need for education and training related to dyslexia among educators. In sum, the studies mentioned here show that this topic requires urgent attention among educators and professionals in Turkey. Therefore, researchers should continue to explore this area in order to enhance understanding, knowledge, and a positive attitude toward dyslexia.

\subsection{Present Study}

In order to measure primary school teachers' knowledge and perception levels regarding dyslexia, the present study aimed to develop a reliable and valid scale using data from Turkey. Through this scale, the study investigated measurement invariance across groups to test the comparability of the subgroups. How teachers' knowledge and perception of dyslexia differ based on their background was also examined.

\section{METHOD}

\subsection{Participants}

The participants of the study were 201 primary school teachers who volunteered to participate. The study included 145 female (72.1\%) and 56 male teachers $(27.9 \%)$. Teaching experiences of teachers ranged from 1 to 23 years. The mean of the teaching experience was 11.01, the median was 10.00 , and the standard deviation was $5.67 .19 .4 \%$ of the teachers stated that they had never heard the term dyslexia. $87.1 \%$ of the teachers reported not having taken a course on dyslexia during their university education. Most of the teachers $(93.5 \%)$ had not yet taken an in-service training of dyslexia. The vast majority of them $(75.6 \%)$ did not read a book or an article on dyslexia. The majority of the teachers (70.1\%) did not teach a student with dyslexia, and most of them $(82.6 \%)$ thought that they had inadequate academic knowledge to teach a student with dyslexia. 


\subsection{Instrument}

\subsubsection{Teachers' knowledge and perception scale}

The aim of the study was to develop a scale to measure primary school teachers' knowledge and perception of dyslexia. The scale was hypothesized to measure two dimensions: teachers' knowledge of dyslexia and teachers' perception of dyslexia. Based on a detailed literature review, investigation of current dyslexia questionnaires (Akçay, 2014; Yurdakal, 2014), and experts' suggestions, a pool of items was developed by the researchers. Fifty-six items were developed initially to measure teachers' knowledge of dyslexia and perception of dyslexia. Table 1 provides a table of specification of the scale. The scale included 5-point Likert scale items. In the scale, teachers were asked to give 1 point to strongly disagree and 5 to strongly agree.

Table 1. Table of Specification.

\begin{tabular}{ll}
\hline Dimensions & Item Numbers \\
\hline Knowledge of Dyslexia & $1,2,3,4,5,6,7,8,9,11,12,13,14,15,16,17$, \\
& $18,32,33,36,37,42,43,47,49,52,53,55$ \\
Perceptions of Dyslexia & $10,19,20,21,22,23,24,25,26,27,28,29,30$, \\
& $31,34,35,38,39,40,41,44,45,46,48,50,51$, \\
& 54,56 \\
\hline
\end{tabular}

Items related to knowledge of dyslexia are statements that focus on the goals that a dyslexic student can achieve and cannot achieve. For example, the items 'A student with dyslexia experiences difficulties in remembering the seasons and months in order' and 'A student with dyslexia needs to read the same paragraph again and again' are items related to knowledge of dyslexia. Items measuring teachers' perception of dyslexia are either pedagogical statements or statements about the general perception of dyslexia. For example, 'Dyslexia is a disease' and 'A student with dyslexia should not receive an education with other students' are exemplar items of perception dimension of the scale.

The questionnaire's demographic part had items related to gender, years of teaching experience, education level, and the type of department they graduated from. Additionally, this part of the scale aimed to get more data about teachers regarding dyslexia and included seven yes-no questions related to dyslexia. Yes or no questions ranged from: "Did you take a course on dyslexia during your university education?" to "Have you ever taken an in-service seminar on dyslexia?"

\subsection{Data Analysis}

The scale was first administered to 30 teachers in order to control the clarity and the language of the statements. All of the teachers were from public schools. The statements were revised according to the feedback of these 30 teachers and a researcher group's suggestions. For instance, the question, "Do you think that you have sufficient academic knowledge to teach a student with dyslexia?" in the demographic part was included in the final form based on this feedback.

After completing the revisions, the scale was administered to the sample. In order to decide the dimensions and related items, exploratory factor analysis using the principal axis factor extraction technique with direct oblimin rotation was conducted. Problematic items that had 0.400 or less item loadings to a primary factor were discarded. Also, if an item was loaded to two factors simultaneously (factor loading difference of an item to a primary factor and other factor is less than 0.100) that item was also eliminated (Field, 2013). 
The reliability of the data was evaluated using Cronbach's alpha coefficient. A reliable scale should have 0.70 or above Cronbach's alpha coefficient. Cronbach's alpha value above 0.70 is acceptable, 0.80 is good, and 0.90 and above is excellent. Higher values mean the data has higher internal consistency (George \& Mallery, 2001)

To collect further evidence regarding the scale's structure, measurement invariance analysis for gender groups was conducted. As the differences between gender groups is a topic of interest of many researchers, providing evidence regarding measurement invariance for gender groups is required for valid comparisons. Having measurement invariance across gender groups implies that the scale scores of males and females can be comparable. To test measurement invariance, the fit values obtained in configural, metric and scalar models are compared. In the configural model, whether the same factor structure exists across the gender is tested. In the metric model, factor loadings of the BTPS were constrained to be equal across the gender groups. In the scalar model, item thresholds are constrained to be equal for males and females in addition to the factor loadings (Milfont \& Fischer, 2010; Vandenberg \& Lance, 2000). Measurement invariance is assessed by comparing $\triangle \mathrm{CFI}$ and $\triangle \mathrm{RMSEA}$ values with cutoff criteria $(\Delta \mathrm{CFI} \leq .01, \Delta \mathrm{RMSEA} \leq .015)$ suggested by Chen $(2007)$ and Cheung and Rensvold (2002).

After deciding the items related to each dimension, teachers' knowledge and perception scores were calculated. These scores were used to conduct correlational analysis and group comparison analysis to achieve the study's second goal. For the correlational analysis, the significance, direction, and magnitude of the relationship is evaluated. For the group comparisons, independent samples $t$-test was conducted and effect size $(d)$ was estimated. According to Cohen (1988), $d$ value around 0.20 represents a small difference, 0.50 means medium difference, and 0.80 implies large differences between the groups.

\section{RESULT / FINDINGS}

\subsection{Factor Structure of the Scale}

The exploratory factor analysis was conducted and items that did not belong to any factor were eliminated. Kaiser-Meyer-Olkin's measure of sampling adequacy value of .840 indicated that the underlying factors might cause the proportion of variance in the items. Bartlett's test of sphericity $(\mathrm{p}<.05)$ showed that the correlation matrix was different from an identity matrix. Therefore, the data was appropriate for conducting the exploratory factor analysis. As a result of the exploratory factor analysis procedure, two meaningful factors emerged. These twofactors explained $51 \%$ of the total variance. Table 2 shows factor loadings obtained as a result of exploratory factor analysis. Factor one included the items 16, 15, 9, 11, 8, 13, 18, 12, 3 and 17. All of the ten items were related to primary school teachers' knowledge of dyslexia as hypothesized. Therefore, the first dimension was named as knowledge of dyslexia. Factor two had the items $28,24,19,20,27$, and 21 . These 6 items were related to primary teachers' negative perception of dyslexia. The second dimension was called as perception of dyslexia. 
Table 2. Rotated Factor Matrix of Exploratory Factor Analysis.

\begin{tabular}{lll}
\hline & \multicolumn{2}{c}{ Factor } \\
\cline { 2 - 3 } Item Number & 1 & 2 \\
\hline q16 & .747 & \\
q15 & .736 & \\
q9 & .721 & \\
q11 & .707 & \\
q8 & .703 & \\
q13 & .655 & \\
q18 & .630 & \\
q12 & .613 & \\
q3 & .575 & \\
q17 & .522 & .753 \\
q28 & & .675 \\
q24 & & .652 \\
q19 & & .649 \\
q20 & & .585 \\
q27 & & .549 \\
q21 & & \\
\hline
\end{tabular}

\subsection{Reliability of the Scale}

In order to examine the reliability of the scale, Cronbach's alpha coefficient was calculated for each dimension (see Table 3). Knowledge and perception dimension's alpha values indicated good internal consistency. Additionally, Cronbach's alpha value for all items was reported.

Table 3. Cronbach's Alpha Coefficients.

\begin{tabular}{llll}
\hline & \multicolumn{3}{c}{ Dimensions } \\
\cline { 2 - 4 } & Knowledge & Perception & All Items \\
\hline Cronbach's Alpha & .89 & .81 & .78 \\
Number of items & 10 & 6 & 16 \\
\hline
\end{tabular}

\subsection{Measurement Invariance across Gender Groups}

Configural, metric and scalar invariance of the scale across gender groups was evaluated (see Table 4). Configural invariance results indicated that fit indexes were within acceptable level $(\mathrm{TLI}=.904, \mathrm{CFI}=.918, \mathrm{RMSEA}=.100)$. This means that the factor structure of the scale was similar for males and females. Metric invariance results showed that the change in the metric model's fit values supported the invariance $(\triangle \mathrm{CFI}=.003, \Delta \mathrm{RMSEA}=-.005)$. Metric invariance means that the factor loadings were equivalent across gender groups. Scalar invariance results showed that the fit values' change supported the invariance $(\triangle \mathrm{CFI}=-.007, \Delta \mathrm{RMSEA}=-.009)$. Scalar invariance means that item thresholds were invariant and the mean score of males and females were comparable. 
Table 4. Measurement Invariance Analysis Results of the Scale.

\begin{tabular}{llllllclc}
\hline & $\chi^{2}$ & $d f$ & $\chi^{2} / d f$ & $T L I$ & $C F I$ & $\begin{array}{c}\text { RMSEA } \\
(90 \% \mathrm{CI})\end{array}$ & $\Delta$ CFI & $\Delta$ RMSEA \\
\hline Configural & 412.12 & 206 & 2.02 & .904 & .918 & $\begin{array}{c}.100 \\
(.086-.114)\end{array}$ & - & - \\
Metric & 418.30 & 220 & 1.90 & .914 & .921 & $\begin{array}{c}.095 \\
(.081-.108) \\
.086\end{array}$ & .003 & -.005 \\
Scalar & 465.15 & 266 & 1.75 & .921 & .928 & $\begin{array}{c}.073-.099) \\
(.073\end{array}$ & .007 & -.009 \\
\hline
\end{tabular}

Note. $\chi^{2}=$ Chi-square, $\mathrm{df}=$ degrees of freedom, TLI $=$ Tucker Lewis index, CFI $=$ comparative fit index, RMSEA = root mean square error of approximation; $\mathrm{CI}=$ confidence interval, $\triangle \mathrm{CFI}=$ change in values of CFI, $\triangle$ RMSEA $=$ change in values of RMSEA.

\subsection{Descriptive Statistics of Scale Scores}

The descriptive statistics of scale scores were reported in Table 5. The minimum plausible score was 10 and the maximum score was 50 for the knowledge factor. For the perception factor, the plausible minimum score was 6 and the maximum score was 30. Skewness and kurtosis values and histogram of the distributions indicated that knowledge scores had normal distribution and perception scores had right-skewed distribution.

Table 5. Descriptive Statistics of Dimensions,

\begin{tabular}{lcc}
\hline & Knowledge & Perception \\
\hline Mean & 36.98 & 12.38 \\
Median & 37.00 & 12.00 \\
Std. Deviation & 7.37 & 5.35 \\
Minimum & 13.00 & 6.00 \\
Maximum & 50.00 & 30.00 \\
Skewness & -0.02 & 0.76 \\
Kurtosis & -0.35 & 0.12 \\
\hline
\end{tabular}

\subsection{Knowledge of Dyslexia and Related Demographic Variables}

A high score on knowledge factor indicated a teacher has more knowledge about dyslexia. The results of Pearson Product Moment correlation analysis showed that there was no significant relationship between teachers' teaching experience and their knowledge of dyslexia $(r=.01, p$ $>.05)$. Teachers' knowledge of dyslexia did not differ with regard to taking a course $(t(196)=$ $-.06, p>.05)$, taking an in-service seminar of dyslexia $(t(196)=.59, p>.05)$, reading a book or an article of dyslexia $(t(196)=-1.35, p>.05)$, and teaching a student with dyslexia $(t(196)$ $=-1.10, p>.05)$.

\subsection{Perception of Dyslexia and Related Demographic Variables}

High scores on this factor indicate teachers have negative perceptions regarding dyslexia. The correlational analysis results showed a weak positive relationship between primary school teachers' experience and their perception of dyslexia $(r=.20 p<.01)$. This means that experienced teachers have more negative perceptions regarding dyslexia. The results of the $t$ test indicated that there was a significant difference between teachers' perception of dyslexia concerning taking a course on dyslexia $(t(193)=3.06, p<.05)$ and the effect size is large; $d=$ -.82. Primary school teachers who took a course about dyslexia during university education had lower negative perception $(M=9.22, S E=.73)$ compared to primary school teachers who did not take a course about dyslexia during university education $(M=12.78, S E=.41)$. On the other hand, there was no significant difference between teachers' perception of dyslexia with regard to taking an in-service seminar of dyslexia $(t(193)=-.81, p>.05)$, with regard to reading a 
book or an article on dyslexia $(t(193)=1.05, p>.05)$ and with regard to teaching a student with dyslexia $(t(193)=.57, p>.05)$.

\section{DISCUSSION and CONCLUSION}

This study aimed to develop and validate a scale on primary school teachers' knowledge and perception regarding students with dyslexia. Evidence regarding the measurement invariance across gender groups was provided. This study also examined the factors related to teachers' knowledge and perception of dyslexia. The demographic questions provided an overview of teachers' knowledge and perception regarding dyslexia.

\subsection{Scale Development}

The primary aim of the study was to develop and validate a scale on primary school teachers' knowledge and perception of dyslexia. Compared to other studies, such as Gwernan-Jones \& Burden's (2010) study, the main focus of the present study was to design and develop its own questionnaire for primary school teachers. It was shown in the current study that the scale measures two dimensions which are knowledge and perception of dyslexia. Teachers' Knowledge and Perception of Dyslexia Scale was shown to be a reliable scale with good internal consistency. Evidence related to the validity of the scale was also provided. This scale fills the gap in measuring teachers' knowledge and perception of dyslexia in Turkey and could be used in other studies to measure teachers' knowledge and perception of dyslexia. Measurement invariance results imply that the scores obtained using this scale could be used to compare gender groups.

\subsection{Factors Related to Dyslexia}

In the study, factors related to teacher knowledge and perception regarding students with dyslexia were also investigated. The results showed that there was not a significant relationship between teachers' knowledge of dyslexia and their teaching experience. In other words, teachers' knowledge of dyslexia did not increase based on the years they spent teaching. This finding of the study is similar to Akçay (2014). In her study, Akçay (2014) reported that primary school teachers' awareness levels did not change according to their teaching experience. On the contrary, Doğan (2013) revealed that novice teachers were much more knowledgeable about dyslexia than experienced teachers. Ferrer et al. (2016) reported that long years of teaching provided teachers with knowledge of dyslexia. In other words, according to Ferrer et al. (2016), experienced teachers are much more knowledgeable about dyslexia. Overall, in Turkey, there is a need for in-service training to improve teacher knowledge of dyslexia.

The current study found a weak positive relationship between primary school teachers' perception of dyslexia and their teaching experience. Similarly, Yurdakal (2014) reported that teachers' perception of educational activities regarding dyslexia differs according to their teaching experience and novice teachers have much more positive perceptions. It is shown in the current study that experienced teachers are more likely to perceive dyslexia more negatively. These results of the study may be due to the fact that a large percentage of the teachers (77.1 $\%)$ who participated in the study did not take a course about dyslexia. Studies have revealed that teachers who were trained on dyslexia are more likely to have a positive perception of dyslexia (Hornstra et al., 2010). Additionally, primary school teachers who took a course about dyslexia during their university education had lower negative perceptions compared to primary school teachers who did not do so. In that regard, the current study has similar findings with Hornstra et al. (2010). These findings suggest that there is a need to educate experienced teachers who have not taken a course related to dyslexia.

Another finding of the study is related to teaching a student with dyslexia. The results showed that there was not a significant difference between teachers' knowledge of dyslexia and 
teachers' perception of dyslexia between those who taught a student with dyslexia and those who did not. This result is consistent with the results of the study conducted by Altuntas (2010) reporting that teaching a student with dyslexia did not contribute to teachers' knowledge. On the other hand, these findings are inconsistent with the findings of Ferrer et al. (2016). They reported that teachers' knowledge of dyslexia was related to being exposed to a student with dyslexia. The experience a teacher had and the support provided the teacher when teaching a student with dyslexia might affect the knowledge.

\subsection{Teachers and Dyslexia}

Demographic questions of the study also provided important information regarding to teachers and dyslexia. Findings of the study indicated that $19 \%$ of the primary school teachers, which is not a negligible percentage, did not hear the term dyslexia. This finding is consistent with Bingöl (2003), who reported that teachers were not aware of the term dyslexia. When primary school teachers' knowledge of dyslexia was investigated, interestingly enough, teachers reported that they had accurate knowledge of dyslexia. On the other hand, the amount of teachers $(19 \%)$ who have misconceptions of dyslexia and do not have accurate knowledge of dyslexia should be taken into consideration. This finding indicates that not all of the primary school teachers are aware of the term dyslexia and they lack of the necessary knowledge to distinguish and support a student with dyslexia. Similarly, Başar and Göncü (2018) reported that primary school teachers have a conceptual misunderstanding about learning disabilities. Based on the findings of the study, many primary school teachers lacked research-based knowledge or had incorrect information about learning disabilities.

It is evident that primary school teachers play vital roles in the lives of students, especially students with dyslexia. Therefore, having an accurate knowledge of dyslexia is critically important. In this respect, the study has similar findings with Washburn and colleagues (2011) reporting that while some of the teachers have valid knowledge of dyslexia, some teachers have misconceptions about it. Some teachers' lack of knowledge about dyslexia was evident when they were asked to describe dyslexia.

Another interesting finding of the study showed that most teachers $(83 \%)$ did not think that they had sufficient academic knowledge to teach a student with dyslexia. This finding is consistent with other studies reporting that the vast majority of the teachers lacked the necessary training about dyslexia and did not have sufficient skills when teaching students with dyslexia (Altun et al., 2011; Altuntaş, 2010; Bell et al., 2011; Moreau, 2014; Polat et al., 2012). The teacher training programs might be responsible for such a response here. Most of the teachers did not feel well prepared to teach dyslexic students and did not have adequate and accurate knowledge of dyslexia because most of them did not take a course on dyslexia during their university education (87.1\%). According to Ferrer et al. (2016) the fact that teachers lack accurate knowledge of dyslexia is directly related to university coursework, university textbooks, and professional development courses.

In the present study, only a small percentage of the teachers took an in-service seminar on dyslexia $(6.5 \%)$. Also, the findings revealed that there was not a significant difference in teachers' knowledge of dyslexia and teachers' perception of dyslexia even after having taken an in-service seminar. Therefore, these seminars on dyslexia are not reaching teachers and are not effective. The results are consistent with Akçay (2014) who argues that elementary teachers' awareness levels did not differ after taking in-service seminars. Teachers reported that they needed additional training on dyslexia and that they lacked the support they need to teach students with dyslexia (Polat et al., 2012).

Overall, the results of the present study revealed that primary school teachers in Turkey need professional support regarding dyslexia. As in-service teachers are likely to have students with special needs, including students with dyslexia in their classrooms, every teaching education 
program should include courses on dyslexia. (Bos et al., 2001; Hornstra et al., 2010). Studies also reported that professional development and teacher qualification has an effect on teachers' perception of dyslexia (Bos et al., 2001; Hornstra et al., 2010; Mather et al., 2001). If teachers receive training of dyslexia, they have more positive perception of inclusive education. Furthermore, it is reported that teachers who received formal or informal training of dyslexia have more positive perceptions of individualized teaching than those teachers who did not receive training on dyslexia (Hornstra et al., 2010).

Based on the results of the studies here, it is clearly seen that teachers should be provided with specific, valid and research-based education on dyslexia. It is also shown that they are not adequately equipped with the skills to educate students with dyslexia (e.g., Altun et al., 2011; Altuntaş, 2010; Bell et al., 2011; Moreau, 2014; Polat et al., 2012; Şahin et al., 2020). Last but not least, the need for designing powerful, accurate and engaging workshops or seminars is very crucial regarding teacher training on dyslexia. Unfortunately, professional development seminars on dyslexia are, many times, poorly designed and not serving to the needs of the teachers. Therefore, professional development training programs should be given consistently and frequently. Such training programs should (a) be well-designed; (b) include powerful instructional strategies and activities on teaching dyslexia; (c) have up-to-date, evidence-based information about dyslexia.

\subsection{Limitations}

The present study had an important limitation based on sampling technique. Convenience sampling technique was used therefore the results of the study cannot be generalized to entire primary school teachers. There is a need to extend the sample and test the factor structure in future studies. Another limitation was that the current study focused on elementary school teachers. It would add valuable information to the literature to extend the sample by preschool teachers or middle school teachers. Testing discriminant validity with other scales might add value to the study; therefore, future research might be conducted to test the relationships between the current scale and other scales.

\section{Acknowledgments}

This paper was produced from the first author's master dissertation entitled Development of a scale on primary school teachers' knowledge and perception of dyslexia submitted to Boğaziçi University.

\section{Declaration of Conflicting Interests and Ethics}

The authors declare no conflict of interest. This research study complies with research publishing ethics. The scientific and legal responsibility for manuscripts published in IJATE belongs to the author(s). There is not any ethical violation in the study.

\section{Authorship contribution statement}

Duygu Tosun: Investigation, Resources, Visualization, Software, Formal Analysis, and Writing the original draft. Serkan Arıkan: Methodology, Supervision and Validation. Nalan Babür: Investigation, Framing, Supervision and Validation.

\section{ORCID}

\footnotetext{
Duygu Tosun (D) https://orcid.org/0000-0001-5174-3910

Serkan Arıkan (i) https://orcid.org/0000-0001-9610-5496

Nalan Babür (iD https://orcid.org/0000-0002-7052-0488
} 


\section{REFERENCES}

Akçay, D. (2014). Illkokul 1-4. sınıf öğretmenlerinin disleksi ile ilgili farkındalık düzeylerinin incelenmesi [Investigation of elementary school teacher's awareness level of dyslexia]. [Unpublished master's thesis]. Marmara University.

Aktan, O. (2020). Determination of educational needs of teachers regarding the education of inclusive students with learning disability. International Journal of Contemporary Educational Research, 7(1), 149-164. https://doi.org/10.33200/ijcer.638362

Altun, T., Ekiz, D., \& Odabaşı, M. (2011). Sınıf öğretmenlerinin sınıflarında karşılaştıkları okuma güçlüklerine ilişkin nitel bir araştırma [A qualitative study on reading difficulties faced by primary teachers in their classrooms]. Dicle Üniversitesi Ziya Gökalp Ë̆itim Fakültesi Dergisi, 17, 80-101. https://dergipark.org.tr/tr/pub/zgefd/issue/47948/606654

Altuntaş, F. (2010). Sinıf ögretmenlerinin disleksiye ilişkin bilgileri ve dislektik ögrrencilere yönelik çalışmaları [Classroom teachers' knowledge about dyslexia and their trainings for dyslectic students]. [Unpublished master's thesis]. Hacettepe University.

Balcı, E. (2019). Disleksi hakkında öğretmen görüşleri ve karşılaştıkları sorunlar [Teachers' opinions about dyslexia and the challanges they face]. Ege Eğitim Dergisi, 20(1), 162 179. https://doi.org/10.12984/egeefd.453922

Başar, M. \& Göncü, A. (2018). Sınıf öğretmenlerinin öğrenme güçlüğüyle ilgili kavram yanılgılarının giderilmesi ve öğretmen görüşlerinin değerlendirilmesi [Clearing misconceptions of primary school teachers about learning disabilities and evaluation of teacher opinions]. Hacettepe Üniversitesi Eğitim Fakültesi Dergisi, 33(1), 185-206. http://www.efdergi.hacettepe.edu.tr/upload/files/2483-published.pdf

Bell, S., McPhillips, T., \& Doveston, M. (2011). How do teachers in Ireland and England conceptualise dyslexia? Journal of Research in Reading, 34(2), 171-192. https://doi.org/10.1111/j.1467-9817.2009.01419.x

Bingöl, A. (2003). Ankara'da ilkokul 2. ve 4. sınıf öğrencilerinde gelişimsel disleksi oranı [The prevalence of developmental dyslexia among the 2. and 4. grade students in Ankara]. Ankara Üniversitesi Tıp Fakültesi Mecmuast, 56(2), 67-82. https://doi.org/10.1501/Tipf ak 0000000053

Boling, C. J., \& Evans, W. H. (2008). Reading success in the secondary classroom. Preventing School Failure, 52(2), 59-66. https://doi.org/10.3200/PSFL.52.2.59-66

Bos, C., Mather, N., Dickson, S., Podhajski, B., \& Chard, D. (2001). Perceptions and knowledge of preservice and in-service educators about early reading instruction. Annals of Dyslexia, 51, 97-120.

Bos, C., Mather, N., Friedman Narr, R., \& Babur, N. (1999). Interactive, collaborative professional development in early literacy instruction: Supporting the balancing act. Learning Disabilities Research and Practice, 14(4), 227-238.

Brady, S., \& Moats, L. C. (1997). Informed instruction for reading success-foundations for teacher preparation [Paper presentation]. International Dyslexia Association, Baltimore. https://www.researchgate.net/publication/234653061_Informed_Instruction for_Reading_Success_Foundations for Teacher_Preparation

Chen, F. (2007). Sensitivity of goodness of fit indexes to lack of measurement invariance. Structural Equation Modelling, 14, 464-504. https://doi.org/10.1080/107055 $\underline{10701301834}$

Cheung, G. W., \& Rensvold, R. B. (2002). Evaluating goodness-of-fit indexes for testing measurement invariance. Structural Equation Modeling, 9, 233-255. https://doi.org/10.1 207/S15328007SEM0902_5

Cohen, J. (1988). Statistical power analysis for the behavioral sciences (2nd ed.). Lawrence Erlbaum Associates. 
Demir, B. (2005). Okulöncesi ve ilköğretim birinci sınıfa devam eden öğrencilerde özel ögrenme güçlügünün belirlenmesi [Assesment of learning disability in kindergarten and first grade primary school students]. [Unpublished master's thesis]. Marmara University.

Doğan, B. (2013). Türkçe ve sınıf öğretmenlerinin okuma güçlügüüne ilişkin bilgileri ve okuma güçlügü olan öğrencileri belirleyebilme düzeyleri [Determining Turkish Language and elementary classroom teachers' knowledge on dyslexia and their awareness of diagnosing students with dyslexia]. Okuma Yazma Eğitimi Araştırmalarl, 1(1), 20-33. https://dergipark.org.tr/tr/pub/oyea/issue/20479/218123

Esen, A., \& Çiftçi, İ. (2000). Sınıf öğretmenlerinin öğrenme yetersizliği ile ilgili bilgilerinin belirlenmesi. Pamukkale Üniversitesi Eğitim Fakültesi Dergisi, 8(8), 85-90. https://dergipark.org.tr/tr/download/article-file/114887

Ferrer, M. S., Bengoa, C. E., \& Joshi, R. M. (2016). Knowledge and beliefs of developmental dyslexia in pre-service and in-service Spanish-speaking teachers. Annals of dyslexia, 66, 91-110. https://doi.org/10.1007/s11881-015-0111-1

Fırat, T., \& Koçak, D. (2018). Sınıf öğretmenlerinin öğrenme güçlüğünün tanımına ilişkin görüşleri [Investigating the opinions of class teachers' on the concept of learning difficulty]. Abant İzet Baysal Üniversitesi Ĕ̈itim Fakültesi Dergisi, 18(2), 915-931. https://doi.org/10.17240/aibuefd.2018..-431461

Field, A. (2013). Discovering statistics using IBM SPSS statistics. Sage.

Foorman, B. R., \& Moats, L. C. (2004). Conditions for sustaining research-based practices in early reading instruction. Remedial and Special Education, 25(1), 51- 60.

George, D., \& Mallery, P. (2001). SPSS for Windows Step by Step: A Simple Guide and Reference. Allyn \& Bacon.

Gever, A. (2017). Illkokul ve ortaokul müdürlerinin disleksiye ilişkin bilgi düzeylerinin belirlenmesi [Determination of levels of knowledge of discretion of primary and secondary school directors]. [Unpublished master's thesis]. Pamukkale University.

Gwernan-Jones, R., \& Burden, R. L. (2010). Are they just lazy? Student teachers' attitudes of dyslexia. Dyslexia, 16(1), 66-86. https://doi.org/10.1002/dys.393

Hellendoorn, J., \& Ruijssenaars, W. (2000). Personal experiences and adjustment of Dutch adults with dyslexia. Joumal of Remedial and Special Education, 21(4), 227-239. https://doi.org/10.1177\%2F074193250002100405

Hornstra, L., Denessen, E., Bakker, J., van den Bergh, L., \& Voeten, M. (2010). Teacher attitudes toward dyslexia. Effects on teacher expectations and the academic achievement of students with dyslexia. Journal of Learning Disabilities, 43, 515-529. https://doi.org/10.1177\%2F0022219409355479

Lane, H. B., Hudson, R. F., Leite, W. L., Kosanovich, M. L., Strout, M. T., \& Fenty, N. (2009). Teacher knowledge about reading fluency and indicators of students' fluency growth in reading first schools. Reading and Writing Quarterly, 25, 57-86. https://doi.org/10.1080 $/ 10573560802491232$

Mather, N., Bos, C., \& Babur, N. (2001). Perceptions and knowledge of preservice and inservice teachers about early literacy instruction. Journal of Learning Disabilities, 34(5), 472-482. https://doi.org/10.1177\%2F002221940103400508

Milfont, T. L., \& Fischer, R. (2010). Testing measurement invariance across groups: Applications in cross-cultural research. International Journal of Psychological Research, 3(1), 112-131. https://doi.org/10.21500/20112084.857

Mills, C. (2006). Preservice teacher education and the development of socially just dispositions. A review of the literature [Paper presentation]. Annual Conference of the Australian Association for Research in Education, Adelaide. https://www.aare.edu.au/da ta/publications/2006/mil06221.pdf 
Moats, L. (2009). Knowledge foundations for teaching reading and spelling. Reading and Writing: An interdisciplinary Journal, 22, 379-399. https://psycnet.apa.org/doi/10.1007/ s11145-009-9162-1

Moats, L. C., \& Foorman, B. R. (2003). Measuring teachers' content knowledge of language and reading. Annals of Dyslexia, 53, 23- 45. https://doi.org/10.1007/s11881-003-0003-7

Moreau, L. K. (2014). Who's really struggling? Middle school teachers' perceptions of struggling readers. Research in Middle Level Education Online, 37(10), 1-17. https://doi.org/10.1080/19404476.2014.11462113

National Center for Statistics (2008). The condition of education 2008. Indicator 5: Language Minority school aged children. Washington. https://nces.ed.gov/pubs2008/2008031.pdf

Nijakowska, J., Tsagari, D., \& Spanoudis, G. (2018). English as a foreign language training needs and perceived preparedness to include dyslexia learners: The case of Greece, Cyprus, and Poland. Dyslexia, 24, 357-379. https://doi.org/10.1002/dys.1598

Polat, E., Adiguzel, T., \& Akgun, O. E. (2012). Adaptive web-assisted learning system for students with specific learning disabilities A needs analysis study. Educational Sciences Theory and Practice, 12(4), 3243-3258. https://files.eric.ed.gov/fulltext/EJ1003015.pdf

Proctor, C. M., Mather, N., Stephens-Pisecco, T., \& Jaffe, L. E. (2017). Assessment of dyslexia. Communique, 46(3), 1-10.

Rubin, D. (2002). Diagnosis and correction in reading instruction. Allyn and Bacon.

Snow, C. E., Burns, M. S., \& Griffin, P. (1998). Preventing reading difficulties in young children. National Academy Press.

Spear-Swerling, L. (2009). A literacy tutoring experience for prospective special educators and struggling second graders. Journal of Learning Disabilities, 42, 431-443. https://doi.org/10.1177\%2F0022219409338738

Spear-Swerling, L., \& Brucker, P. O. (2004). Preparing novice teachers to develop basic reading and spelling skills in children. Annals of Dyslexia, 54(2), 332-364. https://doi.org/10.1007/s11881-004-0016-X

Şahin, R., Güven, S. \& Alatlı, B. (2020). Sınıf öğretmenlerinin disleksiye yönelik bilgi ve tutumlarının incelenmesi [Investigation of the knowledge and attitudes of primary school teachers towards dyslexia]. Turkish Studies-Education, 15(4), 2355-2372. http://dx.doi.org/10.47423/TurkishStudies.42099

Taylor, B. M., Pressley, M., \& Pearson, P. D. (2002). Research-supported characteristics of teachers and schools that promote reading achievement. In B. M. Taylor, \& P. D. Pearson (Eds.). (2002). Teaching reading: Effective schools, accomplished teachers. (pp. 361-373). Lawrence Erlbaum. https://www.researchgate.net/publication/3 12839932 Research-supported characteristics of teachers and schools that promote reading achievement

Vandenberg, R. J., \& Lance, C. E. (2000). A Review and synthesis of the measurement invariance literature: Suggestions, practices and recommendations for organizational research. Organizational Research Methods, 3, 4-70. https://doi.org/10.1177\%2F10944 2810031002

Vellutino, F. R., Fletcher, J. M., Snowling, M. J., \& Scanlon, D. M. (2004). Specific reading disability (dyslexia). What have we learned in the past four decades. Journal of Child Psychology and Psychiatry, 45(1), 2-40. https://doi.org/10.1046/j.0021-9630.2003.0030 $\underline{5 . \mathrm{X}}$

Washburn, E. K., Joshi, R. M., \& Binks-Cantrell, E. S. (2011). Teacher knowledge of basic language concepts and dyslexia. Dyslexia, 17, 165-183. https://doi.org/10.1002/dys.426

Washburn, E. K., Mulcahy, C. A., Musante, G., \& Joshi, R. M. (2017). Novice teachers' knowledge of reading related disabilities and dyslexia. Learning Disabilities: $A$ Contemporary Journal, 15(2), 169-191. https://files.eric.ed.gov/fulltext/EJ1160653.pdf 
Yurdakal, İ. H. (2014). İlkokullarda okuma güçlüğünde yaşanan sorunlar ile eğitim uygulamalarına ilişkin öğretmen ve ögrenci görüşleri [Teachers' and students' views regarding to problems encountered at primary schools related to reading disorders and educational activities for dyslexic students]. [Unpublished master's thesis]. Pamukkale University. 